\title{
PEMETAAN KARAKTERISTIK KIMIA BIJI KOPI ARABIKA GAYO DAN ROBUSTA GAYO
}

\author{
[Mapping the Chemical Characteristics of Gayo Arabica and \\ Robusta Grean Coffee Beans]
}

\author{
Maya Saputri, Hanifah Nuryani Lioe*, dan C. Hanny Wijaya \\ Departemen IImu dan Teknologi Pangan, Fakultas Teknologi Pertanian, Institut Pertanian Bogor, Bogor
}

Diterima 10 Juli 2019 / Disetujui 18 Mei 2020

\begin{abstract}
The distinctive aroma and taste of roasted coffee can be due to varietal differences in green coffee beans. The purpose of this research was to map the chemical characteristics of green coffee beans of Gayo arabica and Gayo robusta using principal component analysis (PCA) approach. Other analyses include $\mathrm{pH}$ using $\mathrm{pH}$ meter, total fats by Soxhlet method, total ash by gravimetric method, total protein by Kjeldahl method, total carbohydrates by difference, total soluble solids (TSS) by refractometer, organic acids composition by HPLC-UVNVis, and total amino acids composition by UHPLC-PDAD. Six green coffee bean samples of Gayo arabica and Gayo robusta from different locations in Gayo, Aceh, as well as samples of arabica and robusta coffee beans each from plantation in West Java, Central Java and East Java (as comparators) were used in this study. The results showed the chemical characteristics of Gayo arabica and Gayo robusta could be mapped by PCA based on the concentrations of fats, organic acids and carb ohydrates. The organic acid composition of Gayo arabica was associated with malic acid, succinic acid and citric acid, while Gayo robusta to acetic acid. The organic acids as well as TSS of the coffee beans could map Gayo arabica separately from Java arabica. Gayo arabica had higher organic acids, whereas Java arabica had higher TSS. Gayo robusta were characterized by higher fats, ash and total amino acids, but lower TSS than Java robusta. This study suggested the distinct characteristics of Gayo coffee beans to their corresponding coffee beans from Java.
\end{abstract}

Keywords: amino acid composition, chemical characteristic, green coffee beans, organic acid composition, principal component analysis

\begin{abstract}
ABSTRAK
Perbedaan varietas dapat menyebabkan aroma dan rasa khas kopi hasil penyangraian berbeda . Tujuan dari penelitian ini adalah untuk memetakan karakteristik kimia biji kopi hijau arabika gayo dan robusta gayo dengan pendekatan principal component analysis (PCA). Analisis $\mathrm{pH}$ dengan $\mathrm{pH}$ meter, total lemak dengan metode Soxhlet, total abu dengan metode gravimetri, total protein dengan metode Kjeldahl, total karbohidrat by difference, total padatan terlarut (TPT) dengan refraktometer, kompos isi as am organik dengan HPLC-UV/Vis, dan komposisi total asam amino oleh UHPLC-PDAD dari kedua jenis biji kopi dilakukan. Enam sampel biji kopi hijau arabika gayo dan robusta gayo dari berbagai lokasi di Gayo, Aceh, serta sampel biji kopi arabika dan robusta masing-masing dari perkebunan di Jawa Barat, Jawa Tengah dan Jawa Timur (sebagai pembanding) digunakan dalam penelitian ini. Hasil penelitian menunjukkan karakteristik kimia arabika gayo dan robusta gayo dapat dipetakan dengan PCA berdasarkan konsentrasi lemak, asam organik dan karbohidrat. Komposisi asam organik dari arabika gayo dihubungkan dengan asam malat, asam suksinat dan asam sitrat, sementara robusta gayo dengan asam as etat. Asam organik serta TPT biji kopi dapat memetakan arabika gayo terpisah dari arabika jawa. Arabika gayo memiliki asam organik yang lebih tinggi, sedangkan arabika jawa memiliki TPT yang lebih tinggi. Robusta gayo ditandai dengan kadar lemak, kadar abu dan asam amino total yang lebih tinggi, tetapi TPT lebih rendah daripada robusta jawa. Studi ini menunjukkan karakteristik biji kopi hijau baik arabika maupun robusta dari Gayo berbeda dengan karakteristik biji kopi hijau sejenis dari Jawa.
\end{abstract}

Kata kunci: biji kopi, karakteris tik kimia, komposisi asam amino, komposisi asam organik, principal component analysis

${ }^{*}$ Penulis Korespondensi: E-mail: hanifahlioe@apps.ipb.ac.id 


\section{PENDAHULUAN}

Biji kopi dihasilkan dari tanaman kopi yang umumnya dipakai sebagai minuman yang memiliki aroma dan rasa yang khas setelah disangrai. Konsumsi kopi di dunia meningkat setiap tahunnya. Hal ini dapat dilihat pada tahun 2012, yaitu konsumsi mencapai 8,5 juta ton (ICO, 2014) dan terus meningkat hingga tahun 2019 yaitu sebanyak 10 juta ton (USDA, 2019).

Genus Coffea arabica dan Coffea robusta yang biasa dikenal dengan kopi arabika dan kopi robusta banyak dibudidaya di Indonesia. Spesies arabika mendominasi dataran tinggi dengan ketinggian 6001800 meter dpl, sedangkan spesies kopi robusta tumbuh di daerah yang kurang dari 1000 meter dpl. (Frega et al., 2015). Kopi arabika dan robusta juga mengalami waktu pemanenan dan proses pengolahan pasca panen yang berbeda (Velasques et al., 2019). Proses pengolahan pasca panen yang dimaksud, yaitu proses kering dan proses basah (Lee et al., 2015) yang juga umum ditemukan pada biji kopi dalam perdagangan internasional. Perbedaan tersebut mengakibatkan perbedaan karakteristik kimia biji kopi. Komposisi kimia yang berbeda memberikan citarasa kopi sangrai (untuk kopi siap konsumsi) yang berbeda.

Menurut Rendon et al. (2014) kopi arabika memiliki flavor dan rasa yang lebih disukai oleh para konsumen dibandingkan kopi robusta. Tingginya kualitas citarasa kopi arabika menyebabkan nilai komersial kopi tersebut juga tinggi, hal ini memungkinkan terjadinya pencampuran antara kopi arabika dan robusta (Giraudo et al., 2019) dalam perdagangan. Pencampuran dapat terjadi baik pada bij kopi (sebelum disangrai) maupun kopi yang telah disangrai. Selain itu, menurut penelitian Teuber (2010), daerah asal kopi merupakan penentu penting harga kopi di pasar. Hal ini memungkinkan kopi jenis tertentu tetapi dari daerah berbeda (berbeda varietas) dicampur. Perbedaan varietas biji kopi telah dikenali dari komposisi kimia, terutama komposisi fraksi berberat molekul besar (protein teranalisis pada $280 \mathrm{~nm}$ ) maupun komponen volatilnya (Smrke et al., 2015) yang didukung dengan uji statistik multivariate analysis menggunakan principal component analysis (PCA). Uji statistik dengan multivariate analysis juga berhasil membedakan kopi berbeda varietas dari berbagai daerah, hanya dari karakteristik komposisi mineral biji kopi (Habte et al., 2016).

Biji kopi arabika ditandai dengan ukuran yang lebih besar, berbentuk oval dan warna hijau pucat sedangkan biji kopi robusta ditandai dengan ukuran yang lebih kecil, cenderung bulat dan warnanya yang kecokelatan (Ghosh dan Venkatachalapathy, 2014). Pencampuran biji kopi dapat dikenali dengan mengetahui karakteristik kimia maisng-masing biji kopi seperti komposisi asam amino (Dong et al.,
2017), komposisi asam organik (Borem et al., 2016; Casas et al., 2017) dan kandungan kafein (Dong et al., 2017). Karakteristik kimia biji kopi dari Gayo, baik arabika maupun robusta yang produknya diketahui memiliki preferensi konsumen yang relatif tinggi di Indonesia, belum diungkap dengan baik. Tujuan dari penelitian ini adalah mengetahui karakteristik kimia biji kopi hijau yang berasal dari Gayo, baik arabika gayo maupun robusta gayo, serta memetakannya dan membandingkannya dengan karakteristik biji kopi sejenis dari Jawa. Uji statistik dengan PCA digunakan untuk tujuan pemetaan ini.

\section{BAHAN DAN METODE}

\section{Bahan}

Bahan utama yang digunakan dalam penelitian ini adalah biji kopi arabika gayo (Coffea arabica L.) dan robusta gayo (Coffea robusta L.) yang diperoleh dari petani kopi di tiga lokasi berbeda di dataran tinggi Gayo, yaitu: untuk kopi arabika gayo diperoleh dari (1) Kecamatan Kabayakan, (2) Kecamatan Jaluk dan (3) Kecamatan Bintang, selanjutnya disebut sampel $A G 1, A G 2$ dan $A G 3$, sedangkan untuk biji kopi robusta gayo diperoleh dari (1) Kecamatan Lut Tawar, (2) Kecamatan Ketol dan (3) Kecamatan Blang Mancung, Provinsi Aceh, selanjutnya disebut sampel RG 1, RG 2 dan $R G$ 3. Biji kopi arabika dan robusta pembanding diperoleh dari petani kopi di berbagai provinsi di Pulau Jawa: (1) Jawa Timur, (2) Jawa Barat dan (3) Jawa Tengah, selanjutnya masing-masing disebut sampel AJ 1, AJ 2 dan AJ 3 untuk arabika jawa, sedangkan sampel robusta jawa diberi kode RJ 1, RJ 2 dan RJ 3. Pengambilan sampel dilakukan dua ulangan (duplikat). Dalam penelitian ini, diketahui dari petani kopi bahwa biji kopi arabika baik dari Gayo maupun dari Jawa semuanya diproses dengan cara basah, sedangkan biji kopi robusta baik dari Gayo maupun dari Jawa diproses dengan cara kering.

\section{Persiapan sampel}

Sampel biji kopi yang berwarna hijau dan kering dari petani kopi direduksi ukurannya sebelum dianalisis dengan cara digiling menggunakan penggilingan tradisional buatan lokal yang digerakkan dengan listrik (Grinding machine, CV. Agromesin, Indonesia) dengan kapasitas $250 \mathrm{~g}$ biji kopi dan selanjutnya hasil gilingan berupa bubuk diseragamkan ukurannya menggunakan saringan ukuran 40 mesh. Hal ini dilakukan agar memudahkan homogenisasi sampel, sehingga memberikan hasil analisis yang lebih baik. Sampel dikemas dalam kantong plastik berbahan polietilen berlapis dua dan disimpan pada suhu refrigerator $\left(4-10^{\circ} \mathrm{C}\right)$ hingga dilakukan analisis. Cara persiapan sampel ini mengikuti persiapan sampel pada penelitian biji kopi arabika 
dan robusta yang dilakukan oleh Dias dan Benassi (2015).

\section{Karakterisasi kimia biji kopi}

Setiap sampel biji kopi dari persiapan sampel di atas dianalisis proksimat, $\mathrm{pH}$, total padatan terlarut (TPT), komposisi asam organik dan komposisi asam amino. Prosedur analisis dijelaskan di bawah ini. Analisis proksimat dilakukan mengikuti metode AOAC (2012). Analisis terdiri dari analisis kadar air dengan cara gravimetrik menggunakan oven biasa pada suhu $105^{\circ} \mathrm{C}$, analisis kadar abu dengan cara gravimetrik menggunakan tanur pada suhu $550^{\circ} \mathrm{C}$, analisis kadar lemak dengan cara gravimetrik menggunakan alat ekstraksi Soxhlet dan oven biasa pada suhu $105^{\circ} \mathrm{C}$, analisis kadar protein dengan cara titrimetrik menggunakan alat destruksi dan destilasi Kjeldahl, dan analisis kadar karbohidrat diakukan dengan cara by difference. Analisis dilakukan duplo. Pengukuran $\mathrm{pH}$ dilakukan menggunakan $\mathrm{pH}$ meter (Eutech Instrument, Singapore) dengan cara sebagai berikut. Sampel biji kopi sebanyak 1,0 g yang sudah dihaluskan, ditambahkan $100 \mathrm{~mL}$ akuades dan dihomogenkan selama 10 menit. $\mathrm{pH}$ meter dikalibrasi menggunakan bufer standar $\mathrm{pH} 4$ dan 7 (Merck, Jerman). Selanjutnya $\mathrm{pH}$ sampel diukur duplo.

Pengukuran total padatan terlarut (TPT) dilakukan dengan refraktometer Abbe (Atago, Japan). Sampel biji kopi yang telah dihaluskan sebanyak 1,0 g ditambah $5 \mathrm{~mL}$ akuades dan dibaca kadar padatan terlarutnya pada skala ${ }^{\circ}$ Brix. Pengukuran dilakukan duplo.

Analisis komposisi asam organik dilakukan mengikuti prosedur Borem et al. (2016). Sebanyak $1,0 \mathrm{~g}$ sampel biji kopi yang telah dihaluskan diekstraksi menggunakan $50 \mathrm{~mL}$ air deionisasi pada suhu $70^{\circ} \mathrm{C}$ selama 30 menit. Selanjutnya ekstrak ditepatkan volumenya menggunakan labu ukur 100 $\mathrm{mL}$ dengan penambahan fase gerak HPLC yaitu 4 $\mathrm{mM}$ asam sulfat (Merck, Jerman) dalam akuabides lalu disaring. Kemudian $3 \mathrm{~mL}$ ekstrak disaring SPE silika 60 sekitar $1 \mathrm{~g}$ (Merck, Jerman). Penentuan kuantitatif asam organik (asam oksalat, asam asetat, asam malat, asam sitrat, asam suksinat dan asam format (Bio-Rad, Amerika Serikat) dilakukan menggunakan HPLC-UV/VIS (MWD) Agilent 1200 series (Agilent Technologies, USA) dengan kondisi sebagai berikut: kolom: Aminex HPX-87H $300 \times 7,8$ mm, BioRad; fase gerak: $4 \mathrm{mM}$ asam sulfat dalam akuabides; waktu elusi: 20 menit; laju alir: 0,6 mL/menit; suhu kolom: suhu ruang; volume sampel: $20 \mu \mathrm{L}$; detektor: Multiwavelength detector (MWD); deteksi: UV pada $215 \mathrm{~nm}$. Kuantifikasi dilakukan dengan perbandingan luas area peak sampel dengan peak yang berkaitan dari standar. Larutan standar yang terdiri dari campuran asam oksalat $72,02 \mu \mathrm{g} / \mathrm{mL}$, asam sitrat $768,50 \mu \mathrm{g} / \mathrm{mL}$, asam malat 1072,70 $\mu \mathrm{g} / \mathrm{mL}$, asam suksinat $2361,80 \mu \mathrm{g} / \mathrm{mL}$, asam format $920,50 \mu \mathrm{g} / \mathrm{mL}$, dan asam asetat $2402,00 \mu \mathrm{g} / \mathrm{mL}$ diinjeksi ke HPLC pada kondisi yang sama secara terpisah.

Analisis komposisi asam amino dilakukan dengan hidrolisis $0,1 \mathrm{~g}$ sampel biji kopi yang telah dihaluskan menggunakan $5 \mathrm{~mL} \mathrm{HCl} 6 \mathrm{~N}$ selama 22 jam pada suhu $110^{\circ} \mathrm{C}$. Hasilnya ditepatkan dengan labu ukur $50 \mathrm{~mL}$ memakai akuades. Hidrolisat disaring menggunakan membran PVDF 0,45 $\mu \mathrm{m}$ (Milipore, Amerika Serikat). Filtrat yang dihasilkan dipipet sebanyak $500 \mu \mathrm{L}$ dan ditambah larutan standar internal alpha amino butyric acid (AABA) sebanyak 40 dan $460 \mu \mathrm{L}$ akuades. Campuran larutan tersebut dipipet kembali sebanyak $10 \mu \mathrm{L}$ dan kemudian ditambah $70 \mu \mathrm{L}$ AccQ-Fluor borat dan $20 \mu \mathrm{L}$ AccQ Tag Fluor reagen sebagai pengekstrak. Larutan diinkubasi selama 10 menit pada suhu $55^{\circ} \mathrm{C}$ dan siap untuk dianalisis. Metode ini mengikuti prosedur dari Waters Corporation (2012). Penentuan kuantitatif asam amino dilakukan menggunakan UPLCPDAD (Waters Corporation, USA) dengan kondisi sebagai berikut: Kolom: AccQ-Tag Ultra C18 (2,1 $\times 100 \mathrm{~mm}$ ); temperatur: $49^{\circ} \mathrm{C}$; fase gerak: sistem komposisi gradien yang terdiri dari fase gerak $A$ : Eluent AccQ-Taq Ultra from water (part no. 186003838), fase gerak $B$ : $10 \%$ fase gerak $D$, fase gerak C: air Milli-Q, fase gerak D: Eluent AccQ-Taq Ultra from Waters (part no. 186003839); Laju alir: $0,7 \mathrm{~mL}$ per menit; Detektor: photo diode array (PDA), deteksi pada panjang gelombang UV 260 $\mathrm{nm}$; volume injeksi: $10 \mu \mathrm{L}$.

\section{Analisis statistik}

Data dianalisis menggunakan one way analysis of varians (ANOVA). Jika terdapat perbedaan nyata yang signifikan maka diuji lebih lanjut menggunakan uji Duncan (DMRT) pada $P<0,05$, menggunakan SPSS 20.0. Pemetaan data hasil analisis dilakukan dengan analisis multivariat principal component analysis (PCA) menggunakan XLSTAT versi 2016.02. 28451 (Addinsoft, Amerika) berdasarkan karakteristik kimia biji kopi yang dianalisis.

\section{HASIL DAN PEMBAHASAN}

\section{Karakteristik kimia biji kopi arabika gayo}

Biji kopi arabika yang berasal dari berbagai lokasi di daerah Gayo, yaitu AG 1, AG 2 dan AG 3, dihasilkan melalui proses basah yaitu melibatkan proses fermentasi yang dilakukan oleh para petani. Berdasarkan hasil analisis biji kopi arabika gayo (Tabel 1), nilai $\mathrm{pH}$ yang diperoleh bervariasi antara 5,2 hingga 5,8, sedangkan $\mathrm{pH}$ sampel biji kopi arabika jawa berkisar antara 4,9 hingga 5,3, dengan demikian pH sampel biji kopi arabika gayo relatif lebih tinggi daripada arabika jawa. 
Tabel 1. Komposisi kimia biji kopi arabika dan robusta dari Gayo dan Jawa

\begin{tabular}{lcccc}
\hline \multirow{2}{*}{ Komposisi } & \multicolumn{4}{c}{ Konsentrasi } \\
\cline { 2 - 5 } & Arabika Gayo & Arabika Jawa & Robusta Gayo & Robusta Jawa \\
\hline Kadar air (\% bk) & $116,44 \pm 20,58$ & $106,91 \pm 8,07$ & $107,79 \pm 5,55$ & $104,39 \pm 0,53$ \\
Kadar abu (\% bk) & $4,67 \pm 0,97$ & $4,27 \pm 0,68$ & $4,97 \pm 0,19$ & $4,77 \pm 0,64$ \\
Kadar protein (\% bk) & $14,90 \pm 1,49$ & $14,75 \pm 0,70$ & $16,13 \pm 0,67$ & $16,52 \pm 0,96$ \\
Kadar lemak (\% bk) & $13,91 \pm 2,81$ & $14,75 \pm 1,08$ & $13,15 \pm 3,54$ & $10,67 \pm 0,52$ \\
Kadar karbohidrat (\% bk) & $66,50 \pm 0,45$ & $66,54 \pm 0,24$ & $65,74 \pm 2,68$ & $68,04 \pm 1,58$ \\
pH & $5,66 \pm 0,39$ & $5,10 \pm 0,17$ & $4,89 \pm 0,44$ & $5,71 \pm 0,61$ \\
TPT (\% bk) & $12,74 \pm 3,99$ & $14,83 \pm 1,85$ & $14,09 \pm 3,35$ & $17,90 \pm 1,97$ \\
Asam amino total (\% bk) & $13,09 \pm 1,96$ & $10,61 \pm 0,74$ & $14,28 \pm 3,23$ & $12,00 \pm 1,77$ \\
Asam organik total (\% bk) & $2,03 \pm 1,50$ & $1,52 \pm 0,84$ & $3,50 \pm 0,66$ & $2,22 \pm 1,31$ \\
\hline
\end{tabular}

Keterangan: ${ }^{*} \%$ bk adalah persentase $\mathrm{g} / 100 \mathrm{~g}$ berdasarkan basis kering. Nilai tidak berbeda nyata diantara sampel arabika dan robusta $(P>0,05)$. TPT adalah total padatan terlarut (refraktometer Abbe)

Menurut literatur, pH biji kopi arabika berkisar antara 5,30 hingga 6,07 (Abubakar et al., 2011; Lee et al., 2017), dengan demikian biji kopi arabika gayo masuk dalam rentang ini. Fermentasi biji kopi yang terjadi pada proses basah dapat menyebabkan peningkatan kadar asam laktat pada biji kopi arabika, sehingga dapat menurunkan $\mathrm{pH}$ dan meningkatkan keasaman biji kopi (Afriliana et al., 2018). Asam laktat diproduksi selama fermentasi biji kopi karena aktivitas mikroba. Asam laktat tidak dianalisis karena keterbatasan senyawa standar yang tersedia tetapi jenis asam organik lain dapat dianalisis (Gambar 1), yaitu asam asetat, asam sitrat, asam malat dan asam suksinat, yang dominan ditemukan pada biji kopi arabika gayo, serta biji kopi robusta gayo.

Nilai TPT sampel biji kopi arabika gayo, berkisar 9,39-17,16\% bk, relatif lebih kecil dibandingkan nilai TPT biji kopi arabika jawa yang berkisar 13,37$16,91 \%$ bk (Tabel 1). Padatan terlarut diantaranya berupa asam organik, asam amino dan karbohidrat sederhana dapat berkontribusi terhadap citarasa dan pembentukan aroma kopi yang telah disangrai (Borem et al., 2016). Proses fermentasi yang diterapkan pada biji kopi arabika gayo kemungkinan berbeda dari proses pengolahan biji kopi arabika jawa, sehingga memberikan nilai TPT yang bervariasi.

Pada penelitian ini, kisaran total asam organik sampel biji kopi arabika gayo adalah $0,68-3,65 \%$ bk. Total asam organik biji kopi arabika jawa relatif lebih rendah akan tetapi berada dalam kisaran total asam organik biji kopi tersebut yaitu $0,82-2,45 \%$ (bk) (Gambar 1). Proses fermentasi dalam pengolahan biji kopi cara basah memengaruhi kadar asam organik biji kopi. Beberapa asam organik yang relatif tinggi konsentrasinya dalam biji kopi arabika adalah asam sitrat, asam malat dan asam asetat (Gambar 1). Asam organik merupakan senyawa penting dalam pembentukan rasa dan aroma kopi setelah disangrai, sehingga kadar asam organik yang lebih tinggi memungkinkan biji kopi arabika gayo memiliki citarasa yang lebih baik dibandingkan arabika jawa (Diviš et al., 2019).

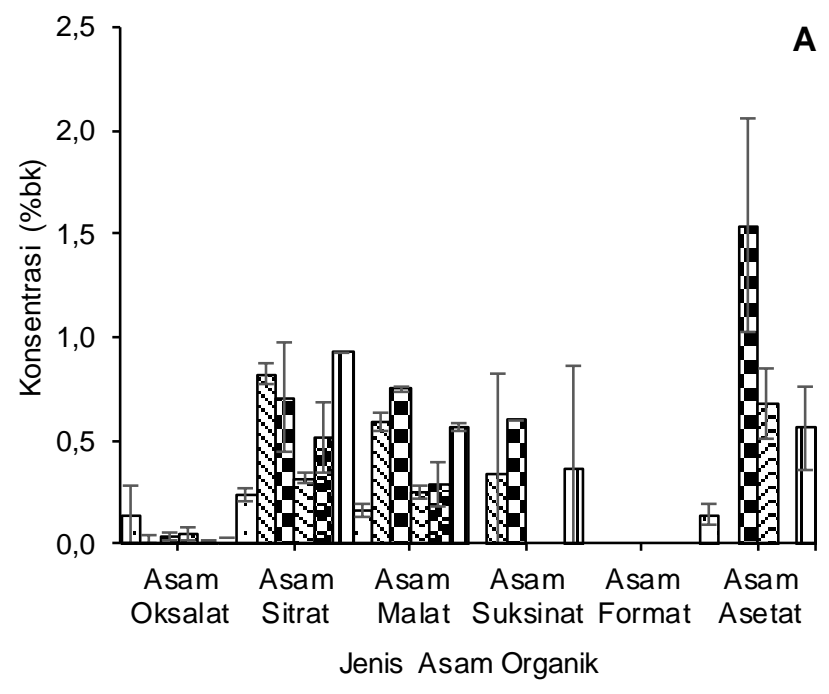

$\square A G 1 \otimes A G 2 \square A G 3 \square A J 1 \square A J 2 \square A J 3$

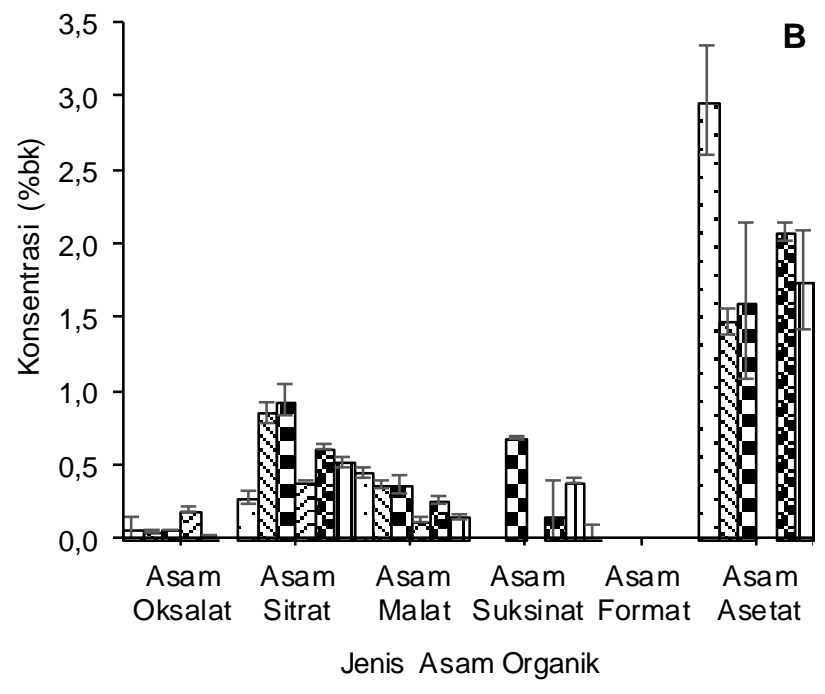

$\square R G 1$ घRG 2 घRG 3 घRJ 1 घRJ 2 घRJ 3

Gambar 1. Komposisi asam organik ( $g / 100 \mathrm{~g}$ biji kopi basis kering) pada: (A) biji kopi arabika (asal dari Gayo AG dan Jawa AJ) dan (B) biji kopi robusta (asal Gayo RG dan Jawa RJ) 
Biji kopi mengandung protein yang lebih tinggi dibandingkan kopi yang telah disangrai, ini diungkapkan Dong et al. (2015) berdasarkan hasil analisis total asam amino. Sebagian asam amino bereaksi membentuk komponen aroma dan warna kopi sangrai. Dengan demikian asam amino yang terkandung dalam biji kopi menentukan karakteristik kopi hasil sangrai. Asam amino total dalam sampel biji kopi arabika gayo berkisar pada 11,04-14,95\% (bk) lebih tinggi $(P<0,05)$ daripada asam amino total dalam sampel biji kopi arabika jawa, pada kisaran 9,81-11,27\% (bk) (Gambar 2A). Proses fermentasi yang diterapkan dapat mengakibatkan konsentrasi asam amino dari biji kopi arabika bervariasi (Lee et al., 2017), sebagaimana yang ditemukan pada sam- pel biji kopi arabika gayo AG 1, AG 2 dan AG 3 yang berasal dari tiga petani di lokasi berbeda yang kemungkinan menerapkan proses pengolahan basah yang berbeda. Berdasarkan hasil analisis pada Gambar 2A, profil komposisi asam amino biji kopi arabika relatif mirip dengan profil komposisi asam amino biji kopi robusta. Meskipun demikian kadar asam amino pada biji kopi robusta lebih tinggi daripada biji kopi arabika (Tabel 1 dan Gambar 2A). Komposisi asam amino pada biji kopi arabika yang berbeda khususnya kadar lisin, valin, isoleusin, fenilalanin, arginin, glisin dan prolin. Perbedaan kadar asam amino ini memungkinkan terjadinya perbedaan citarasa biji kopi apabila telah disangrai (Wong et al., 2008).

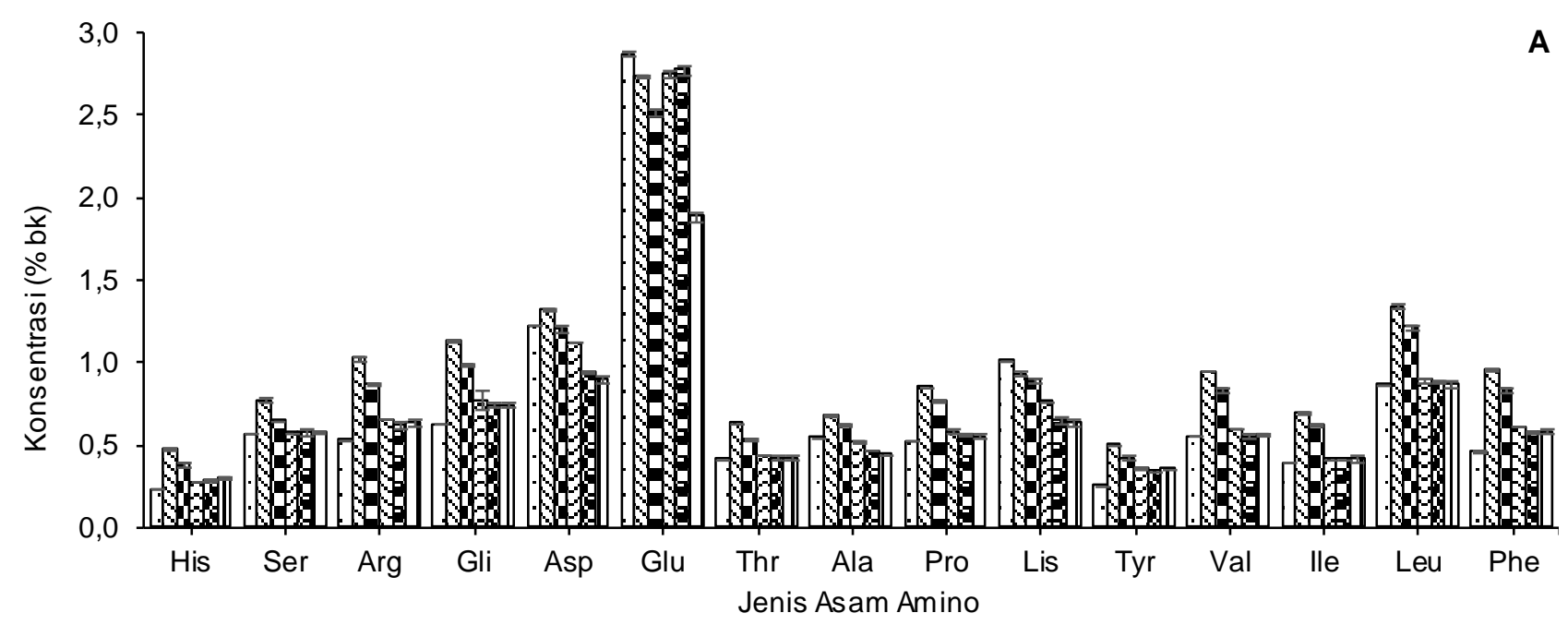

$\square A G 1 \otimes A G 2 \square A G 3 \square A J 1 \square A J 2 \square A J 3$

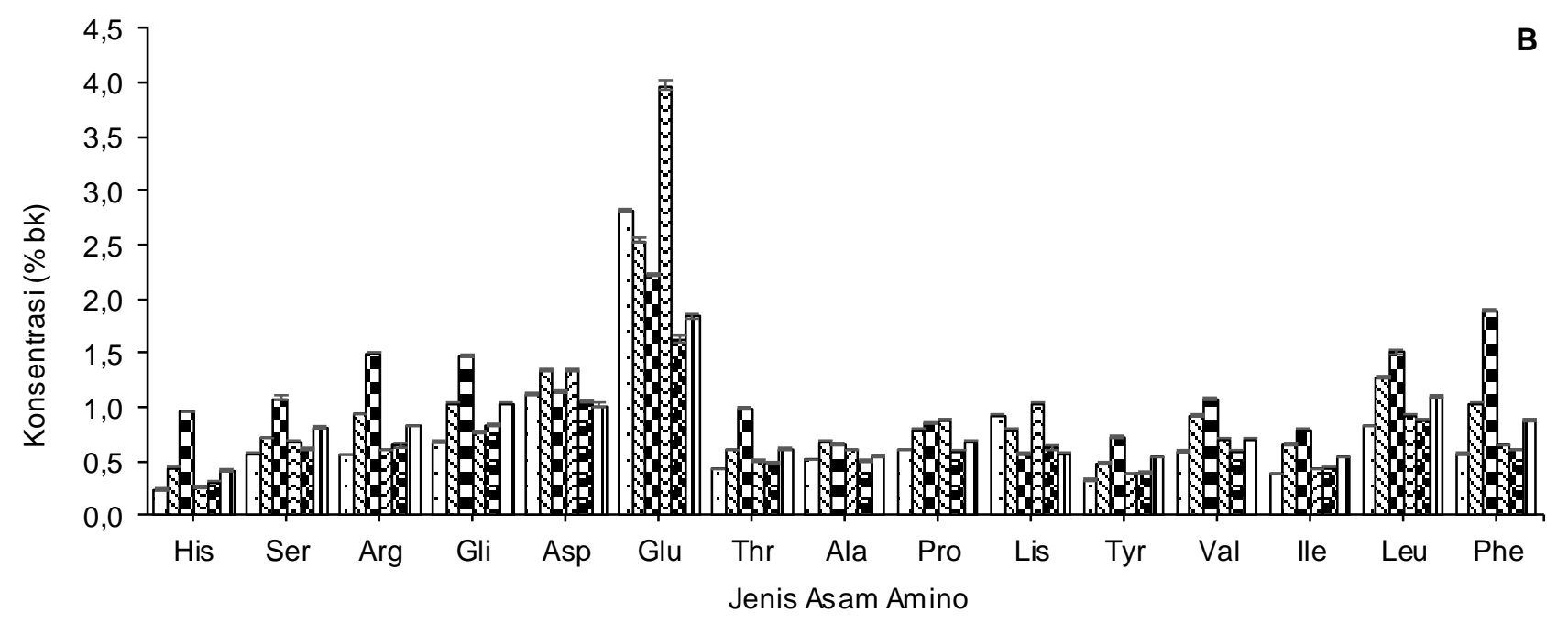

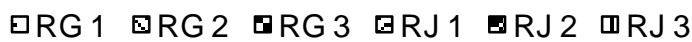

Gambar 2. Komposisi asam amino ( $\mathrm{g} / 100 \mathrm{~g}$ biji kopi basis kering) pada: (A) biji kopi arabika (AG dan AJ) dan (B) biji kopi robusta (RG dan RJ) dari Gayo dan Jawa 


\section{Karakteristik kimia biji kopi robusta gayo}

Tabel 1 menunjukkan karakteristik kimia biji kopi robusta. Hasil analisis $\mathrm{pH}$ menunjukkan $\mathrm{pH}$ sampel biji kopi robusta gayo berkisar 4,60-5,40, lebih kecil daripada $\mathrm{pH}$ sampel biji kopi robusta jawa yang berkisar 5,01-6,12. Hasil analisis total padatan terlarut (TPT) menunjukkan bahwa nilai TPT sampel biji kopi robusta gayo yang berkisar $10,56-17,23 \%$ (bk) lebih kecil dibandingkan nilai TPT sampel biji kopi robusta jawa yang berkisar 16,31-20,10\% (bk) (Gambar 2). Rendahnya nilai TPT dapat berpengaruh terhadap citarasa biji kopi tersebut (Finotello et al., 2017), semakin rendah nilai TPT tetapi total asam organik semakin tinggi seperti pada biji kopi robusta gayo maka akan meningkatkan keasaman biji kopi.

Berdasarkan analisis komposisi asam organik, sampel biji kopi robusta gayo dan robusta jawa keduanya juga didominasi oleh asam asetat, asam sitrat dan asam malat. Total asam organik sampel biji kopi robusta gayo, yaitu $2,74-3,96 \%$ (bk), relatif lebih tinggi $(P<0,05)$ dibandingkan sampel biji kopi robusta jawa, yaitu 0,72-3,14\% (bk) (Gambar 3). Tingginya konsentrasi asam asetat, asam sitrat dan asam malat akan menyebabkan tingginya tingkat keasaman pada biji kopi tersebut, akan tetapi konsentrasi asam asetat yang tinggi juga akan menghasilkan rasa yang tidak disukai (Lee et al., 2017).

Hasil analisis komposisi asam amino menunjukkan total asam amino sampel biji kopi robusta gayo yang berkisar $11,09-17,54 \%$ (bk), lebih tinggi daripada total asam amino sampel biji kopi robusta jawa yang berkisar 10,19-13,72\% (bk) (Gambar 2B). Konsentrasi total asam amino yang lebih tinggi ini dapat memengaruhi kualitas citarasa biji kopi robusta gayo setelah disangrai.

Secara umum, karakteristik kimia biji kopi arabika berbeda dari biji kopi robusta baik yang diperoleh dari tiga lokasi berbeda di daerah Gayo maupun dari tiga provinsi di Pulau Jawa $(P<0,05)$ (Tabel 1). Hal ini dapat dipengaruhi oleh proses pengolahan biji kopi yang berbeda, dimana biji kopi arabika diproses dengan pengolahan basah, sedangkan kopi robusta dengan pengolahan kering sebagaimana diinformasikan dalam bagian Bahan dan Metode. Hal ini sesuai dengan penelitian sebelumnya yang menggunakan sampel biji kopi dari Brasil, India dan Korea (Bicho et al., 2013; Lee et al., 2017), bahwa pH biji kopi arabika dan robusta berbeda. Biji kopi arabika memiliki nilai $\mathrm{pH}$ yang lebih rendah, yaitu $\mathrm{pH}$ biji kopi arabika berkisar 4,60-5,60, sedangkan $\mathrm{pH}$ biji kopi robusta berkisar 5,30-6,10.

Hal yang berbeda dari literatur tersebut, terlihat pada penelitian ini, sampel biji kopi arabika gayo memiliki rata-rata nilai $\mathrm{pH}(5,66)$ sedikit lebih tinggi dibandingkan sampel biji kopi robusta gayo $(4,89)$. Hal ini ditandai dengan kadar asam organik yang lebih tinggi pada biji kopi robusta (Gambar 1). De- ngan demikian, sampel biji kopi robusta gayo memiliki pH yang sangat berbeda dari biji kopi sejenis dari Jawa maupun dari negara lain. Meskipun demikian, penelitian yang telah dilakukan oleh Borem et al. (2016) mengonfirmasi bahwa asam organik pada biji kopi robusta lebih tinggi dibandingkan biji kopi arabika.
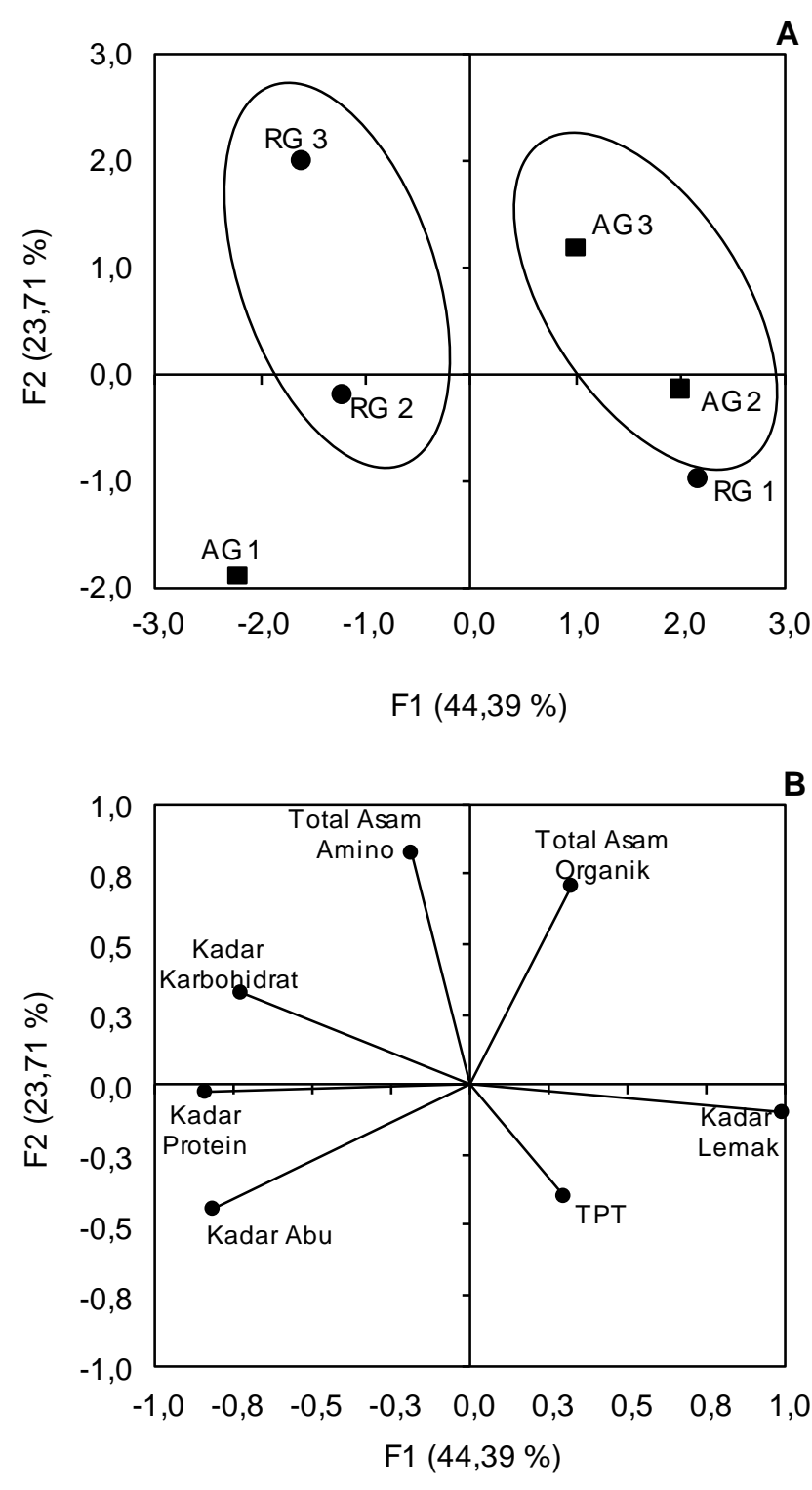

Keterangan: Score plot (A) dan loading plot (B)

Gambar 3. karakteristik kimia biji kopi arabika gayo (AG) dan robusta gayo (RG)

Hasil analisis TPT sampel biji kopi menunjukkan bahwa nilai TPT sampel biji kopi robusta lebih tinggi dibandingkan nilai TPT sampel biji kopi arabika yang berasal dari daerah yang sama. Hal ini sejalan dengan kadar asam organik dan asam amino biji kopi arabika yang lebih rendah daripada biji kopi 
robusta (Gambar 1 dan 2). Selain itu, proses fermentasi yang diterapkan pada biji kopi arabika (proses basah) memengaruhi kadar gula biji kopi arabika, sehingga TPT sampel biji kopi arabika lebih rendah (Finotello et al., 2017).

Hasil yang sama dengan TPT, terdapat pada hasil analisis asam amino biji kopi arabika dan robusta (Gambar 2), biji kopi robusta yang mengalami proses pengolahan kering memungkinkan memiliki konsentrasi asam amino yang lebih tinggi dibandingkan biji kopi arabika yang mengalami proses pengolahan basah $(P>0,05)$. Fakta ini juga terdapat pada hasil penelitian lain (Borem et al., 2016 dan Rodrigues et al., 2007).

\section{Pemetaan karakteristik kimia biji kopi arabika gayo dan robusta gayo}

Pemetaan karakteristik kimia biji kopi arabika gayo dan robusta gayo, arabika gayo dan arabika jawa, serta robusta gayo dan robusta jawa, diperlihatkan pada Gambar 3-6. Hasil analisis PCA yang dilakukan ditampilkan dalam bentuk score plot dan loading plot. Score plot PCA digunakan untuk melihat pemisahan sampel biji kopi, sedangkan loading plot PCA digunakan untuk melihat penyebaran karakteristik kimia yang menentukan pemisahan sampel tersebut (Giraudo et al., 2019; Monakhova et al., 2015).

Hasil analisis PCA biji kopi arabika gayo dan robusta gayo ditunjukkan pada Gambar 3, pemisahan sampel dapat digambarkan oleh $68,11 \%$ keragaman data. Gambar 3A menunjukkan sampel biji kopi arabika gayo (AG 2 dan AG 3) dapat dipisahkan dari biji kopi robusta gayo (RG 2 dan $R G 3$ ), meskipun hanya dua dari tiga sampel yang dapat dipetakan. Pemisahan sampel ini ditentukan oleh karakteristik kadar lemak, total asam organik dan kadar karbohidrat. Pemetaan lebih lanjut komposisi asam organik pada Gambar 4 menunjukkan bahwa asam organik biji kopi arabika gayo berhubungan dengan asam malat, asam suksinat dan asam sitrat, sedangkan sampel biji kopi robusta gayo berhubungan dengan asam asetat.

Hasil pemetaan PCA (Gambar 3) terlihat bahwa karakteristik biji kopi robusta gayo berhubungan dengan kadar abu, kadar karbohidrat dan kadar protein, sedangkan biji kopi arabika gayo berhubungan dengan kadar lemak dan total asam organik. Tingginya kadar lemak biji kopi arabika gayo dapat dipengaruhi oleh ketinggian tempat budidaya biji kopi arabika gayo, yaitu sekitar 1000-1400 m di atas permukaan laut (Wahyuni et al., 2013) lebih tinggi dibandingkan tempat budidaya biji kopi robusta gayo. Semakin tinggi letaknya dari permukaan laut maka sintesis lemak semakin intensif (Towaha et al., 2015). Dalam penelitian ini, karakteristik kimia biji kopi arabika gayo dan robusta gayo dapat dipisahkan. Hal yang sama untuk biji kopi arabika dan ro- busta lain, telah dibuktikan dalam beberapa penelitian (Babova et al., 2017; Ciaramelli et al., 2019).
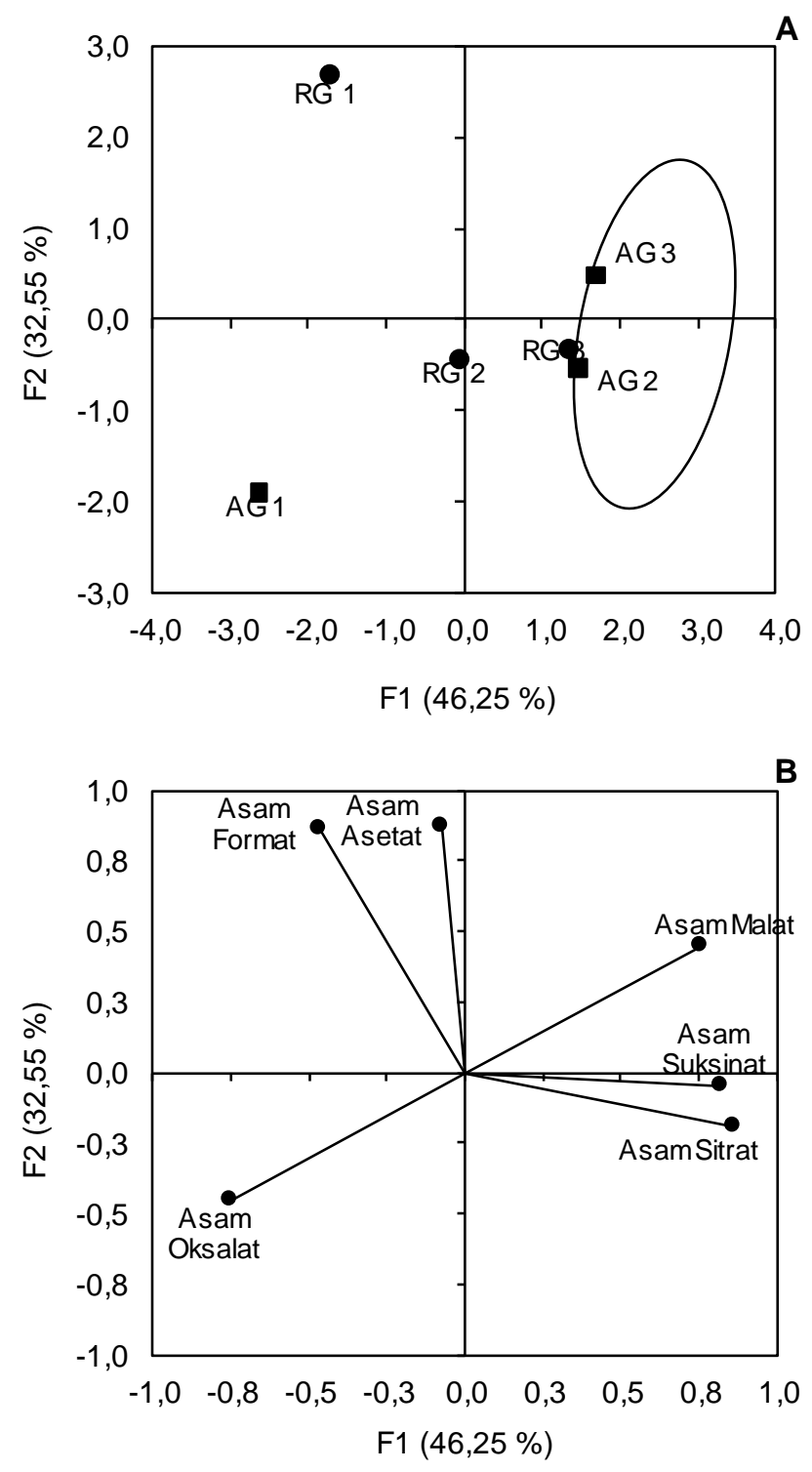

Keterangan: Score plot $(\mathrm{A})$ dan loading plot $(\mathrm{B})$

Gambar 4. komposisi asam organik biji kopi arabika gayo (AG) dan robusta gayo (RG)

Pemetaan karakteristik sampel biji kopi arabika gayo dan arabika jawa menggambarkan $77,09 \%$ variasi data (Gambar 5). Sebagian besar sampel biji kopi arabika gayo dan arabika jawa terlihat jelas dipisahkan oleh komponen utama F2. Karakteristik biji kopi arabika gayo (AG 2 dan AG 3) berhubungan dengan total asam amino dan total asam organik, sedangkan karakteristik biji kopi arabika jawa (AJ 2 dan AJ 3) berhubungan dengan nilai TPT. Hal ini mengungkapkan bahwa sampel biji kopi arabika gayo dapat dibedakan dengan sampel biji kopi arabika jawa berdasarkan karakteristik total asam ami- 
no, total asam organik dan TPT. Tingginya total asam amino dan asam organik yang menjadi karakteristik biji kopi arabika gayo dibandingkan arabika jawa menyebabkan kopi ini memiliki potensi kualitas rasa kopi sangrai yang lebih baik. Hal ini sesuai dengan hasil penelitian sebelumnya oleh Diviš et al. (2019).

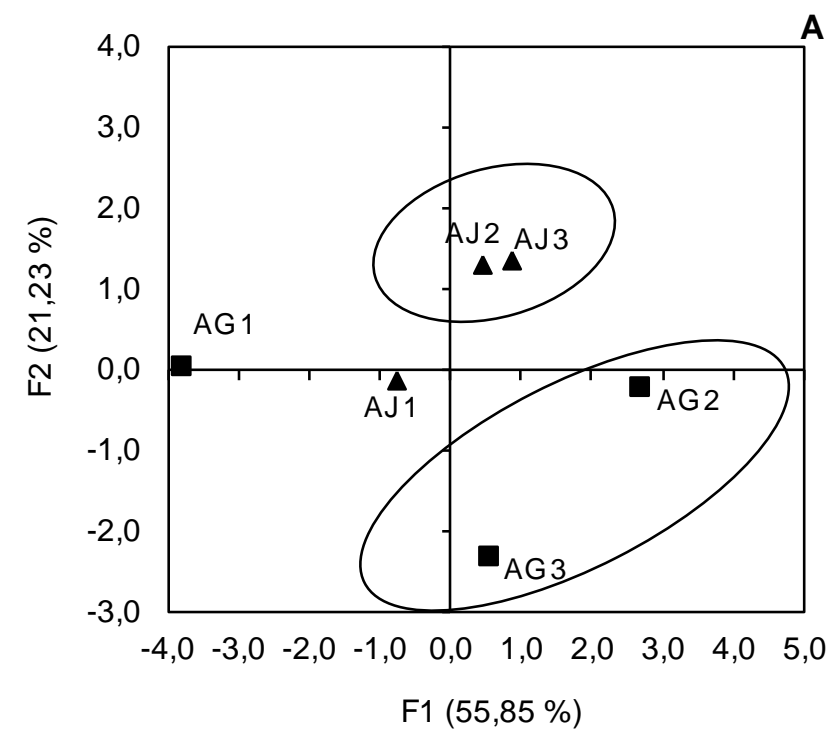

B

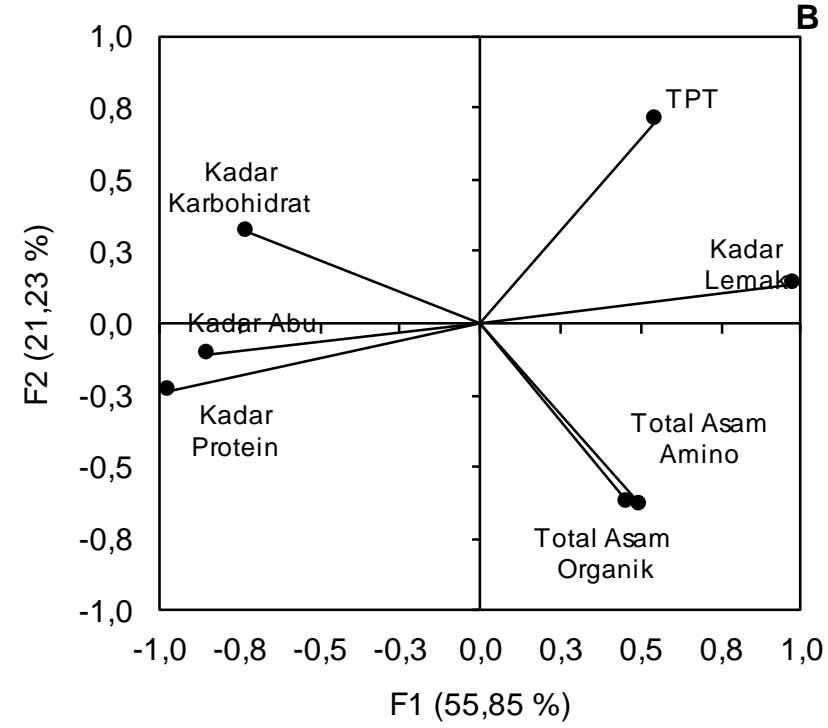

Keterangan: Score plot (A) dan loading plot (B)

Gambar 5. Karakteristik kimia biji kopi arabika gayo (AG) dan arabika Jawa (AJ)

Hasil pemetaan PCA sampel biji kopi robusta gayo dan robusta jawa menggambarkan 76,08\% variasi data (Gambar 6). Pemetaan sampel biji kopi ini juga terutama dipisahkan oleh komponen utama F2. Hasil score plot dan loading plot PCA menunjukkan bahwa sampel biji kopi robusta gayo (RG 1 dan RG 3) berhubungan dengan kadar lemak, kadar abu dan total asam amino, sedangkan karakteristik sampel biji kopi robusta jawa (RJ 2 dan RJ 3) berhubungan dengan nilai TPT. Sampel biji kopi robusta gayo memiliki kadar lemak, kadar abu dan total asam amino yang lebih tinggi, serta nilai TPT lebih rendah dibandingkan sampel biji kopi robusta jawa.
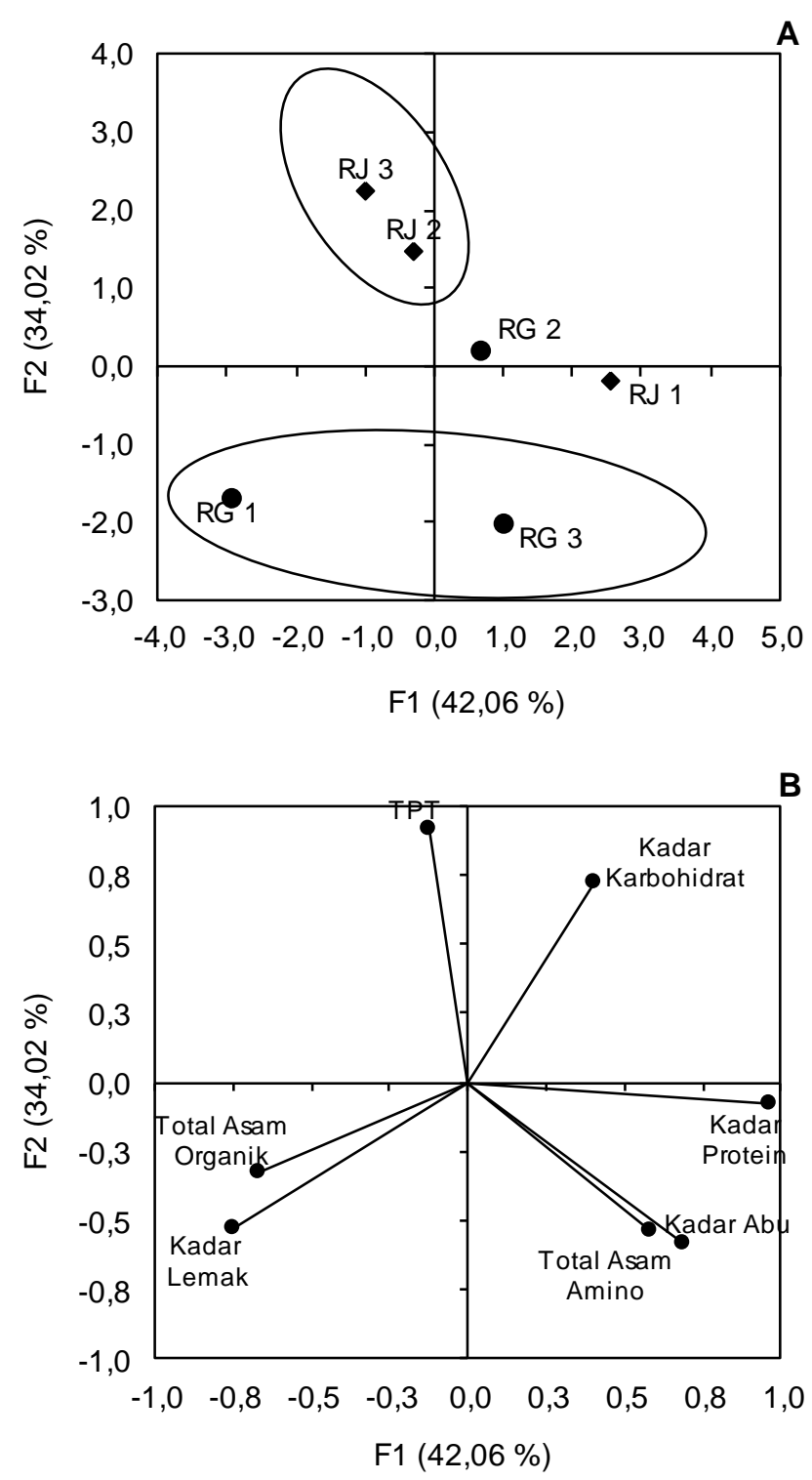

Keterangan: Score plot (A) dan loading plot (B)

Gambar 6. Karakteristik kimia kopi robusta gayo $(R G)$ dan robusta jawa (RJ)

Hasil penelitian ini menunjukkan bahwa karakteristik kimia biji kopi arabika dan robusta dari Gayo dapat dipetakan sebagai biji kopi yang berbeda spesiesnya. Demikian pula bila biji kopi arabika atau robusta gayo dibandingkan dengan biji kopi arabika atau robusta jawa, dalam pemetaan PCA, biji kopi 
berbeda varietas ini dapat dipisahkan berdasarkan karakteristik kimianya. Hal ini sejalan dengan hasil yang dilaporkan oleh Smrke et al. (2015) meskipun menggunakan karakteristik kimia (komponen volatil dan profil berberat molekul besar atau protein pada $280 \mathrm{~nm}$ ) yang berbeda dari penelitian ini.

\section{KESIMPULAN}

Pemetaan karakteristik kimia biji kopi arabika maupun robusta dari daerah Gayo dapat dilakukan melalui principal component analysis (PCA). Pemisahan sampel berdasarkan karakteristik kimianya semakin jelas terlihat apabila karakteristik biji kopi arabika gayo dipetakan terhadap biji kopi arabika jawa, demikian pula karakteristik biji kopi robusta gayo dengan biji kopi robusta jawa,

\section{UCAPAN TERIMAKASIH}

Penulis berterima kasih kepada Lembaga Pengelola Dana Penelitian (LPDP) Republik Indonesia atas dukungan dana selama penelitian dengan kontrak no 20150611033274 Tahun 2015.

\section{DAFTAR PUSTAKA}

Abubakar Y, Karim A, Fahlufi F. 2011. Flavor of arabica coffee grown in gayo plateau as affected by varieties and processing techniques. Proceedings of the Annual International Conference Syiah Kuala University, Banda Aceh. 1: 70-75.

Afriliana A, Harada H, Khotijah PQ, Giyarto, Jayus. 2018. Fermented technology of robusta coffee beans (Canephora coffee) with kefir milk to produce specialty coffee. Adv Eng Res 172: 302309. DOI: 10.2991/fanres-18.2018.61.

[AOAC] Association of Official Analytical Chemist. 2012. AOAC Official Method of Analysis. $19^{\text {th }}$ ed. AOAC International Press, Mayland (USA).

Babova O, Occhipinti A, Maffei ME. 2016. Chemical partitioning and antioxidant capacity of green coffee (Coffee arabica and Coffee canephora) of different geographical origin. Phytochem 123: 33-39. DOI: 10.1016/j.phytochem.2016.01. 016.

Bicho NC, Leitao AE, Ramalho JC, Alvarenga NB, Lidon FC. 2013. Identification of chemical clusters discriminators of arabica and robusta green coffee. Int J Food Prop 16: 985-904. DOI: $10.1080 / 10942912.2011 .573114$.
Borem FM, Figueiredo LP, Ribeiro FC, Taveira JHS, Giomo GS, Salva TJG. 2016. The relationship between organic acid, sucrose and the quality of specialty coffees. Afr J Agric Res 11: 709717. DOI: 10.5897/AJAR2015.10569.

Casas MI, Vaughan MJ, Bonello P, Gardener BS, Grotewold E, Alonso AP. 2017. Identification of biochemical features of defective Coffea arabica L. beans. Food Res Int 95: 59-67. DOI: 10.1016/j.foodres.2017.02.015.

Ciaramelli C, Palmioli A, Airoldi C. 2019. Coffee variety, origin and extraction procedure: Implications for coffee beneficial effects on human health. Food Chem 278: 47-55. DOI: 10.1016/j. foodchem.2018.11.063.

Dias RCE, Benassi MT. 2015. Discrimination between arabica and robusta coffees using hydrosoluble compounds; Is the efficiency of the parameters dependent on the roast degree?. Beverages 1: 127-139. DOI: 10.3390/bevera ges 1030127.

Diviš P, Pořízka J, Kříkala J. 2019. The effect of coffee beans roasting on its chemical composition. Slovak J Food Sci 13: 344-350. DOI: 10.5219/1062.

Dong W, Hu R, Chu Z, Zhao J, Tan L. 2017. Effect of different drying techniques on bioactive components, fatty acid composition, and volatile profile of robusta coffee beans. Food Chem 234: 121-130. DOI: 10.1016/j.foodchem.2017. 04.156.

Dong W, Tan L, Zhao J, Hu R, Lu M. 2015. Characterization of fatty acid, amino acid and volatile compound composition and bioactive components of seven coffee (Coffee robusta) cultivar grown in Hainan Province, China. Molecules 20: 16687-16708. DOI: 10.3390/molecules2009 16687.

Finotello C, Forzato C, Gasparini A, Mammi S, Navarini L, Schievano E. 2017. NMR quantification of 16-0-methylcafestol and kahweol Coffee canephora var. robusta beans from different geographical origins. Food Control 75: 62-69. DOI: 10.1016/j.foodcont.2016.12.019.

Frega NG, Pacetti D, Mozzon M, Balzano M. 2015. Chapter 12-Authentication of coffee blends. Coffee in Health and Disease Prevention. 107115. Academic Press. DOI: 10.1016/B978-012-409517-5.00012-7.

Giraudo A, Grassi S, Savorani F, Gavoci G, Casiraghi E, Geobaldo F. 2019. Determination of the geographical origin of green coffee beans using NIR spectroscopy and multivariate data analysis. Food Control 99: 137-145. DOI: 10.10 16/j.foodcont.2018.12.033. 
Ghosh P, Venkatachalaphaty N. 2014. Processing and drying of coffee -a review. Int $\mathrm{J}$ Eng Res Technol 3: 784-794.

Habte G, Hwang IM, Kim JS, Hong JH, Hong YS, Choi JY, Nho EY, Jamila N, Khan N, Kim KS. 2016. Elemental profiling and geographical differentiation of Ethiopian coffee samples through inductively coupled plasma-optical emission spectroscopy (ICP-OES), ICP-mass spectrometry (ICP-MS) and direct mercury analyzer (DMA). Food Chem 212: 512-520. DOI: 10.10 16/j.foodchem.2016.05.178.

[ICO] International Coffee Organization. 2014. World Coffee Trade (1963-2013): A Review of the Markets, Challenges and Opportunities Facing the Sector. London: International Coffee Council.

Lee LW, Cheong MW, Curran P, Yu B, Liu SQ. 2015. Review-Coffee fermentation and flavorAn intricate and delicate relationship. Food Chem 185: 182-191. DOI: 10.1016/j.foodchem. 2015.03.124.

Lee SJ, Kim MK, Lee KG. 2017. Effect of reversed coffee grinding and roasting process on physicochemical properties including volatile compound profiles. Innov Food Sci Emerg 44: $97-$ 102. DOI: 10.1016/j.ifset.2017.07.009.

Monakhova YB, Ruge W, Kuballa T, Ilse M, Winkelmann O, Diehl B, Thomas F, Lachenmeier DW. 2015. Rapid approach to identify the presence of arabica and robusta species in coffee using ${ }^{1} \mathrm{H}$ NMR spectroscopy. Food Chem 182: 178184. DOI: 10.1016/j.foodchem.2015.02.132.

Rendon MY, Salva TJG, Bragagnolo N. 2014. Impact of chemical changes on the sensory characteristics of coffee beans during storage. Food Chem 147: 279-286. DOI: 10.1016/j.food chem.2013.09.123.
Rodrigues Cl, Marta L, Maia R, Miranda M, Ribeirinho M, Maguas C. 2007. Application of solidphase extraction to brewed coffee caffeine and organic acid determination by UV/HPLC. J Food Compos Anal 20: 440-448. DOI: 10.1016/ $\mathrm{j} / \mathrm{jfca}$ 2006.08.005.

Smrke S, Kroslakova I, Gloess AN, Yeretzian C. 2015. Differentiation of degrees of ripeness of Catuai and Tipica green coffee by chromatographical and statistical techniques. Food Chem 174: 637-642. DOI: 10.1016/j.foodchem. 2014.11.060.

Teuber R. 2010. Geographical Indications of Origin as a Tool of Product Differentiation: The Case of Coffee. J Int Food Agribusiness Marketing 22: 277-298. DOI: 10.1080/089744310036416 12.

Towaha J, Purwanto EH, Supriadi H. 2015. Atribut kualitas kopi arabika pada tiga ketinggian tempat di kabupaten Garut. J TIDP 2: 29-34. DOI: 10.21082/jtidp.v2n1.2015.p29-34.

[USDA] United States Department of Agriculture. 2019. Coffee: World Market and Trade. USA: Foreign Agricultural Service.

Wahyuni E, Karim A, Anhar A. 2013. analisis citarasa kopi arabika organik pada beberapa ketinggian tempat dan cara pengolahannya di dataran tinggi Gayo. J Manajemen Sumberdaya Lahan 2: 261-269.

Waters Corporation. 2012. Amino Acid Analysis Application Notebook. https://www.waters.com/ webassets/cms/library/docs/720006130en.pdf. [19 Juni 2019].

Wong KH, Aziz SA, Mohamed S. 2008. Sensory aroma from Maillard reaction of individual and combinations of amino acids with glucose in acidic conditions. Int $\mathrm{J}$ Food Sci Technol 43: 1512-1519. DOI: 10.1111/j.1365-2621.2006.01 445.x. 